\title{
STATUS DEMOTION IN HIERARCHICAL LOYALTY PROGRAMS: EFFECTS OF PAYMENT SOURCE
}

\begin{abstract}
Hierarchical loyalty programs are being operated currently by many firms to improve customer relationships. While past work has demonstrated the negative effects of status demotion in such programs, research on how these effects may vary across different customer group based on payment source is almost nonexistent. This paper examines the moderating role of payment source ('own money' versus 'others money') on the effects of status demotion on customer attitudes and behavior in hierarchical loyalty programs. Analysis of data collected from members of airline loyalty programs show that the negative effects of status demotion on customer attitudes, loyalty intentions, and share-of-wallet are stronger for demoted 'own money' customers than for demoted 'others money' customers. The study provides a deeper insight about the effects of status demotion and points out that firms could possibly be endangering the loyalty of many potentially valuable customers, in particular among the 'own money' customer group.
\end{abstract}

KEYWORDS: Hierarchical Loyalty programs; psychological ownership; customer demotion; payment source; customer loyalty.

\section{INTRODUCTION}

Loyalty programs have been in use by firms for over two decades as an important component of firm’s strategy to maintain and enhance relationships with customers. In 2010 alone, about 2 billion loyalty program memberships were identified in the US market, yielding 18 memberships per household with a total market value of the points / miles issued to members and sold to third parties approaching about $\$ 47.9$ billion (Hlavinka \& Sullivan, 2011). Because of their size and growth, 
loyalty programs have received considerable attention from the marketing researchers over the years. Existing literature shows the benefits of loyalty programs (Wulf, Odekerken-Schroder \& Iacobucci, 2001; Evanschitzky, Ramaseshan, Woisetschläger, Richelsen, Blut, \& Backhaus, 2012), and the positive impact of loyalty programs on customer share (Verhoef, 2003), increased customer retention (Verhoef, 2003), increased switching barriers (Evanchitzky \& Wunderlich, 2006), and enhanced customer loyalty (Yi \& Jeon, 2003; Ha \& Stoel, 2014; Melnyk \& Bijmolt, 2015).

Loyalty programs often contain a tiered or hierarchical structure to segment customers into different status levels based on their cumulative purchases. Status level in these programs is primarily a loyalty inducing mechanism (Henderson, Beck, \& Palmatier, 2011). The nature and amount of the reward to a member depends on the member's status level in the hierarchical structure and also varies across firms. For example, the British Airways loyalty program hierarchical structure has four different membership tiers - blue, bronze, silver, and gold, while the Starwood preferred guest hotel rewards program offers three tiers - preferred, gold, and platinum. Members move upwards based on the spending level from the lowest tier status that offers little benefits to the highest tier status which provides exclusive benefits.

Prior research (e.g., Lacey, Suh, \& Morgan, 2007; Kim, Lee, Bu, \& Lee, 2009) has shown that that loyalty programs motivate consumers with initial low or moderate patronage levels to purchase more over time to uphold their desired status. Lacey et al. (2007) and Kim et al. (2009) have shown that higher level status in the loyalty programs are linked to higher attitudinal and behavioral loyalty. Also, Liu (2007) has shown that loyalty programs influenced the light users to purchase more and thus contributed to their loyalty towards the firm. Since hierarchical loyalty programs are directly related to the customers' spending levels, companies usually lower customer status within a program once the spending level diminishes. This process is basically known as customer demotion and results in the withdrawal of desired customer status and the advantages associated with it.

Given that status demotions are inexorable elements in the management of loyalty programs, researchers have begun examining the effects of status demotion on loyalty intentions and firm value. 
For instance, Wagner, Hennig-Thurau \& Rudolph (2009) found that loyalty intentions were lower for demoted customers than for those who have never been awarded a preferred status, and that demotions can drive otherwise loyal customers away from a firm. Organizational psychology research also indicates that status reductions drive negative emotions within individual who loses status (Smith, 2002), which eventually induces withdrawal behavior (Trice \& Beyer, 1984).

While past work has demonstrated the negative effects of demotion on customer behavior (Liu, 2007; Wagner et al., 2009; van Berlo, Bloemer, \& Blazevic, 2014), limited research to date has explored how this effect may vary across the two groups of customers: 'own money' and 'others money', based on payment source. 'Own money’ customers are those who pay money obtained through own income, energy, time, efforts, and involvement for their travel; while for 'others money' customers, the payment for travel is essentially made by others (e.g. employer). To the best of our knowledge, no study to date has investigated the role of payment source ('own money' versus 'others money') on the effects of demotion on customer attitudes and loyalty behavior. Such investigation is important as consumers' attitudes and evaluations of a particular firm based on their experiences guide subsequent actions and behavior (Garbarino \& Johnson, 1999). Mere understanding that status demotion has a negative effect on firm value, without a deeper insight into how status demotion affects customer attitudes, which in turn, influence future customer behavior/actions, does not equip decision makers to effectively manage loyalty reward programs for value. A comprehensive understanding of how the attitudes and behavior differs among demoted ‘own money’ customers and demoted ‘others money’ customers could provide crucial insights for relationship marketing managers in designing and implementing effective loyalty reward programs. Thus, our study extends the loyalty program research by exploring whether demoted 'own money' customers and demoted 'others money’ customers differ with regard to customer attitudes and loyalty behavior.

This study contributes to the wider loyalty program research by examining: (i) the effects of demotion on customer attitudes and behavior, and (ii) the moderating role of payment source ('own money' versus 'others money') on the effects of status demotion on customer attitudes and behavior 
in hierarchical loyalty programs. We present a theoretical framework that draws on the theory of psychological ownership (Pierce, Kostova \& Dirks, 2001) and phenomenon of source dependence (Loewenstein \& Issacharoff, 1994) to help explain the differences in the effects of demotion on customer attitudes and loyalty between 'own money' customers and 'others money' customers. Following this, we outline a series of hypotheses based on the theoretical foundation and review of prior literature. Subsequently, we present the results of analysis of data collected from airline hierarchical loyalty program members. We conclude with a discussion of our findings, implications, and possible directions for future research.

\section{THEORETICAL FRAMEWORK}

Our interest lies in understanding the role of payment source ('own money' versus 'others money') on the effects of status demotion in hierarchical loyalty programs on customer attitudes, and subsequent customer behavior. In this study, we define 'own money' customers as those who have been paying money obtained through own income, energy, time, efforts, and involvement for the consumption of a service and thus have attained a particular status in the hierarchical loyalty program. On the other hand, 'others money' customers refer to those who have been consuming a service but the costs of the service has been paid by others (e.g. employers) and thus attain a particular status in the hierarchical loyalty program. Hence the loyalty status attained by 'others money' customers does not stem from the fruits of their own money, energy, time, efforts, and involvement. Since an individual's own effort involves investing time, energy, labor, and effort (Csikszentmihalyi \& Rochberg-Halton, 1981), status in hierarchical loyalty programs bestowed by a firm on its best customers is analogous to achieved status because it comes as the result of customers' own efforts (Drèze \& Nunes, 2009). We use the theory of psychological ownership (Pierce et al., 2001) as a foundation for our conceptual framework in explaining the role of 'own money' vs 'others money' on the effects of status demotion on customer attitudes and behaviors.

\section{The theory of psychological ownership}


Psychological ownership is defined as that state where an individual feels as though the target of ownership or a piece of that target is 'theirs' (i.e., it is MINE!) (Pierce, Kostova, \& Dirks, 2003). The theory of psychological ownership suggests that the concept, 'mine', is extremely important in realms of human life and proposes that the state of psychological ownership arises among individuals from certain processes of association of the individual with the target. Through these processes, individuals become psychologically tied to the target, and the target becomes part of their extended self. Csikszentmihalyi \& Rochberg-Halton (1981) provide numerous insights into the psychological phenomenon of ownership. Pierce et al. (2001) state that psychological ownership reflects a relationship between an individual and an object (material or immaterial in nature) in which the object is experienced as having a close connection with the self, becoming part of the 'extended self'. According to the authors, the state of psychological ownership (i.e., mine-ness and/or our-ness) is comprised of a cognitive and affective core, and reflects an individual's awareness, thoughts, and beliefs regarding the target of ownership.

There are several reasons why individuals come to feel ownership. Pierce, et al. (2003) indicate that factors such as the ability to control the object, coming to know the object intimately, and investing the self in the object to be the antecedents of psychological ownership. The authors point out that, through our labor, we not only invest our time and physical effort but also our psychic energy into the outcome of that labor. They further indicate that the most obvious and perhaps the most powerful means by which an individual invests him/herself into an object is to create it with his/her own labor. Creation involves investing time, energy, and even one's values and identity. Likewise, Locke (1690) contend that we own our labor, and therefore, we are likely to feel that we own which we create, shape, or produce with our labor (Pierce et al., 2001). Furthermore, Csikszentmihalyi and Rochberg-Halton (1981) argue that the investment of an individual's energy, time, effort, and attention into objects causes the self to become one with the object and to develop feelings of ownership toward that object. "Things” are attached to the person who produced them because they are his/hercreation, they derive their being and form from his/her efforts; hence, the 
individual who has created them owns them in much the same way as he/she owns him/herself (Durkheim, 1957). Pierce et al. (2001) indicate a positive and causal relationship between the extent to which an individual invests himself or herself into the potential target of ownership and the degree of ownership the individual feels toward that target. The investment of an individual's self into objects causes the self to become one with the object and to develop feelings of ownership towards that object (Mayhew, Ashkanasy, Bramble, \& Gardner, 2007). Investment of the self allows individuals to see their reflection in the target and feel their own effort in its existence.

When people have a sense of ownership, they experience a connection between themselves and various tangible and intangible "targets” (Belk, 1988). The term "target” in the psychological ownership literature is quite broad. It refers to whatever the object of attachment represents to an individual or group. In the context of hierarchical loyalty programs, the target is the loyalty program status which in turn, leads to program loyalty and company loyalty (Yi \& Jeon, 2003; Liu, 2007; Evanschitzky et al., 2012). In line with the theory of psychological ownership, customers who make purchases with ‘own money’ and attain loyalty program status feel they ‘own’ their loyalty status because the status has been achieved through own efforts. For people who gained status by making purchases from money paid by others (e.g., employer), the psychological ownership towards their loyalty status (object) is lower or non-existent. This is because these individuals do not invest much of themselves in gaining the target (i.e. loyalty program status). For them the money paid to make purchases is not derived from the fruits of their own labor, thus the status is essentially gratuitous. On the other hand, individuals who gained status by making high value/frequent purchases with hard earned money from the fruits of their own labor will have stronger psychological ownership towards their loyalty program status. This is because, the more individuals invest themselves into a target, the stronger their psychological ownership for that target will be (Pierce et al., 2001).

Further, the source dependency theory (Loewenstein \& Issacbaroff 1994) suggests that the value of an item may depend on whether it was earned as a reward for superior performance or as a random lottery prize. The authors show that people value objects more when those objects were 
obtained through exemplary performance at a task than when the objects are perceived as having been received by chance. Also, people experience more intense affect when outcomes are attributed to own skill and efforts rather than to luck (Feather, 1969; Weiner, 1985). Thus, a person’s loyalty program status, which stems from the purchases made out of investments from the person's own labor, causes the person to become one with the loyalty program (object) and develop feelings of strong ownership towards the firm. On the other hand an individual who attained loyalty program status through purchases paid for by others may not feel as strong a sense of ownership towards the object (loyalty program) and thus towards the company as the object does not stem from the fruits of the individual's labor. This link is supported by the phenomenon of source dependence (Loewenstein \& Issacharoff, 1994) which implies that acquiring an object by purchasing it with earned income increases its value compared with acquiring it easily without effort or from money that was not earned (Kamleitner \& Erki, 2013).

\section{Payment source and customer attitudes}

Status awarded by a firm to an 'own money' customer in hierarchical loyalty programs is analogous to achieved status because the status comes as the result of the customer's own efforts (Drèze \& Nunes, 2009). An individual's own effort involves investing time, energy, labor, and effort (Csikszentmihalyi \& Rochberg-Halton, 1981). As pointed out earlier, factors such as the ability to control the object, coming to know the object intimately, and investing the self in the object are the reasons why individuals come to feel psychological ownership (Pierce et al., 2003). There has been both theoretical and empirical support for a relationship between psychological ownership and individual attitudes such as satisfaction, trust, and commitment. For example, Buchko (1992) found that psychological ownership positively influences an individual's satisfaction. Similarly, Van Dyne and Pierce (2004) and Mayhew et al. (2007) demonstrate positive links between psychological ownership and job satisfaction. Also, Beggan (1992) and Nuttin (1987) indicate that the association between feelings of ownership and satisfaction applies in relationships between consumers and a 
product or service. For the purpose of this study, we draw on Oliver (1997) and Verhoef et al. (2002) to define satisfaction as the customer's affective state resulting from an overall appraisal of the experience with the airlines loyalty program.

Lee et al. (2015) stressed the importance of trust as a one of the key antecedents of loyalty. Trust is defined as confidence in an exchange partner's reliability and integrity (Wulf et al., 2001; Morgan \& Hunt, 1994). Trust captures the belief that the seller will stand by their word (Anderson \& Narus, 1990) and fulfil promised role obligations (Scheer \& Stern, 1992). Chi \& Han (2008) mentioned that psychological ownership of the employees for their organization fosters their trust towards the employer as well as the organization. Also, the link between psychological ownership and trust has been established by Henssen, Voordeckers, Lambrechts, \& Koiranen (2014) who found that both individual-oriented and collective-oriented psychological ownership are antecedents of stewardship behavior which is a determinant of trust (Reinke 2004).

Kamleitner \& Erki (2013) mentioned that customer behavior towards an object and its seller is a function of how consumers feel about both the object and its seller. Lawler (1992) suggests that in order to develop organizational commitment, employees must psychologically feel as if they own the organization. Similarly, it has been found that psychological ownership positively influences individuals’ organizational commitment (Mayhew et al. 2007; Buchko, 1992). Long (1978) suggested that ownership would lead to greater organizational commitment. On the other hand, weak psychological ownership could lead to negative outcomes. For example, Druskat \& Pescosolido (2002) found that a reduction in team psychological ownership has been related to reduced levels of organizational commitment. Jussila, Tarkiainen, , Sarstedt, \& Hair (2015) stated about the existence of association between feelings of ownership and consumer attitudes (e.g. satisfaction and commitment) and consumer behavior (e.g. word-of-mouth). For the purpose of our study, commitment is defined as the consumer's voluntary willingness to remain in and make efforts towards maintaining a relationship (Morgan \& Hunt, 1994). Commitment encourages exchange parties to resist short-term benefits in favor of the expected long-term benefits of remaining in the 
relationship (Morgan \& Hunt, 1994). In the context of hierarchical loyalty programs, it could be inferred that people who pay with their own money are likely to have higher levels of commitment towards the loyalty program (object) in comparison to those who pay with others money. Payment source may influence psychological ownership through the extent of personal investment. According to Buchko (1992), ownership is often viewed as a financial investment made by employees. This investment is less salient when paying with others money than paying with own money. Thus, we expect consumers to experience higher levels of commitment arising out of higher psychological ownership towards the loyalty program if they pay from their own money as opposed to others money. Based on the above discussion, we hypothesize that:

H1a-c: 'Own money’ customers will have higher (a) satisfaction, (b) trust, and (c) commitment towards a company than 'others money’ customers.

\section{Status demotion and customer attitudes}

Given that psychological ownership (Pierce et al., 2003) is characterized by the feeling that something is "mine”, such feelings of ownership has important psychological and behavioral effects. While growth of possessions produce a positive and uplifting effect (Formanek, 1994), the loss of possessions leads to "shrinkage of our personality, a partial conversion of ourselves to nothingness" (James, 1890, pp. 178). Emotions spark when we experience the invasion of what we feel is 'ours' (Pierce et al., 2001). Thus, invasion of ownership leads to emotions of a sense of loss. In the context of hierarchical loyalty programs, when customers are demoted to a lower status, the demotion is essentially an invasion of the customers feeling of ownership towards the object (i.e., loyalty program), which in turn, dilutes the customer’s emotions, attitudes and feelings towards the firm/brand (Evanschitzky et al., 2012; Liu, 2007; Yi \& Jeon, 2003). This effect is particularly stronger for 'own money' customers than for 'others money' customers. This is because 'own money’ customers have a greater sense of ownership towards the object (loyalty program) and thus towards the company as the object stems from the fruits of their own labor. On the other hand, 
'others money' customers do not feel a strong sense of ownership towards the object (i.e., loyalty program) and towards the company as the object does not result from their own labor. For 'own money' customers, status demotion that results in the withdrawal of preferred status and the benefits associated with, is essentially an invasion of ownership and can cause negative effects, which in turn can drive an otherwise loyal customer away from the firm (Wagner et al., 2009). From this, we infer that while demotion generally has a negative effect on customer attitudes and behavior towards a loyalty program, the negative effect tend to be stronger for 'own money' customers who attain the status through own labor than 'others money’ customers. Thus, we hypothesize that:

H2a-c: The negative effect of status demotion on (a) satisfaction, (b) trust, and (c) commitment towards a company will be stronger for 'own money’ customers than 'others money’ customers.

\section{Status demotion and the effects of customer attitudes on loyalty intentions}

Marketing literature consistently identifies satisfaction, trust, and commitment as the key antecedents of loyalty. Satisfied customers are more likely to have favorable attitudes for staying with their existing service providers, while dissatisfied customers are likely to exhibit disloyalty towards their provider (Oliver, 1997). Past research has consistently shown that trust is a key determinant of loyalty (e.g., Lee et al., 2015; Paulssen, Roulet \& Wilke, 2014). When consumers trust the brand, product or company, they are likely to exhibit strong loyalty intentions. On the other hand, declining trust in a brand has adverse effects on loyalty intentions (Paulssen, Roulet \& Wilke, 2014). Similarly, while commitment has been considered one of the precursors of customer loyalty (Evanschitzky et al., 2012; Fullerton, 2003; Verhoef, 2003), reduced commitment causes customers to be disloyal towards the firm or brand (Wirtz, Mattila \& Lwin, 2007).

While the effect of satisfaction, trust, and commitment on loyalty intentions have been well documented in the literature, we believe that payment source ('own money' vs 'others money') may moderate these relationships. Based on the theory of psychological ownership, the negative effects of 
customer's satisfaction, trust and commitment on loyalty among the demoted customers depend to a great extent on their level of psychological ownership towards the loyalty program (object). As a customer's level of psychological ownership is based on his/her overall assessment of the investment he/she makes into an object to create it (Pierce et al., 2003; Csikszentmihalyi \& Rochberg-Halton, 1981), when a customer perceives invasion (i.e. status demotion) into something that he/she created by investment of self, s/he will have a higher tendency of feeling a sense of loss. On the other hand, the feeling of investment of self is non-existent among customers who have obtained the loyalty program status (object) without any investment of own labor. Hence status demotion is likely to cause more intense sense of loss to 'own money' customers than 'others money' customers. This is likely to be reflected in terms of stronger negative effects which in turn results in weaker attitudinal response (loyalty intentions) for ‘own money’ customers than ‘others money’ customers. This means that the effect of satisfaction, trust and commitment on loyalty intentions will be weaker for demoted 'own money’ customers than for demoted 'others money' customers. Our position here is that while satisfaction, trust and commitment influence loyalty intentions in general, this effect will be weaker for demoted 'own money' customers due to stronger sense of loss arising out of invasion into their psychological ownership than demoted 'others money' customers. Therefore we hypothesize that:

H3a-c: The effect of (a) satisfaction, (b) trust, and (c) commitment on loyalty intentions will be weaker for demoted 'own money' customers than for demoted 'others money’ customers.

\section{Status demotion and the effects of loyalty intentions on share-of-wallet}

Past research has shown that positive customer attitudes positively influence customer behavior (e.g., Anderson et al., 2004). Positive influence of loyalty intentions on share-of-wallet is well established in the marketing literature (e.g., Wirtz, Mattila \& Lwin, 2007). Vogel et al. (2008) demonstrated the effect of loyalty intentions in creating significant value for firms. 
In the context of loyalty programs, our position is that while loyalty intentions positively influence share-of-wallet, this effect will be weaker for demoted 'own money' customers due to the invasion into their psychological ownership arising out of demotion than demoted 'others money' customers. For demoted 'own money' customers, the sense of loss will be stronger, which in turn results in weaker behavioral response (share-of-wallet) as compared to ‘others money’ customers. The theory of psychological ownership provides support for this argument as an invasion into psychological ownership (i.e. status demotion) triggers strong negative affect due to emotions derived from a sense of loss (Pierce et al., 2001). Hence, we hypothesize:

H4: The effect of loyalty intentions on share-of-wallet will be weaker for demoted 'own money' customers than for demoted 'others money’ customers.

\section{METHOD}

Data for the study was collected from airline travellers who are members of any airline loyalty program. To identify potential respondents, experienced field researchers intercepted airline travellers at domestic and international terminals of major airports in Australia. After brief introduction, the interviewers asked the respondents two screening questions: "Are you currently a member of any airlines loyalty reward program?” and "Has your most frequented airline loyalty program status changed in the past 12 months?” Data was collected through face-to-face interviews with a structured survey questionnaire.

We employed quota sampling approach to 'demoted' in status in the past 12 months and 'no change' in status in the past 12 months' categories to ensure adequate responses for these two customer categories. Airline travelers who are members of any airline loyalty program and had their status 'promoted' in the past 12 months' were not considered for the study. Our final sample included 
410 participants (207 'demoted' and 203 'no change') with an average age of 31 years, average income of $\$ 46,000$ per annum, and $49 \%$ females.

To minimize the effects of common method bias we employed several methods . In the survey instrument we included a combination of attitudinal and behavioral measures, and a reverse coded item that enabled us to control for possible common method bias through psychological separation of the measurement (Podsakoff et al., 2003). At the time of the introduction, the interviewer assured respondents' anonymity and requested for their honest responses, which reduced respondents' intent to evaluate on apprehension and thus controlled for possible sources of method bias (Podsakoff et al., 2003). Also, based on Harman's single-factor test, the un-rotated factor solution was run for all the items used in the study. This generated more than a single-factor suggesting absence of common method bias (Podsakoff et al., 2003).

\section{Control variable}

Purpose of travel plays an important role in customers’ attitudes and behavior towards the airline (Morrison, 1996). Although consumers may travel for numerous reasons such as business, visiting friends and relatives, pleasure and other personal business purposes, their travel purpose can be categorized primarily into two groups: business and leisure (Morrison, 1996). Business travellers are distinct from the leisure travellers in terms of their needs, wants and overall travel behavior (McIntosh \& Goeldner, 1990). For instance, business travellers value convenience and reliability, while leisure travellers value price savings and entertainment. Therefore, business and leisure travellers may exhibit different attitudes and behaviors. Thus, to provide rigorous tests of the proposed theoretical model and to control for extraneous variation (Stein \& Ramaseshan, 2015), we included purpose of travel as a control variable in our analysis. This covariate helps to account for respondent heterogeneity and avoid confounding influences on the results (Dawes, 2009).

\section{Measures}


We adapted four items from Oliver (1980) to measure satisfaction. Trust was measured by using four items from Grégoire, Tripp, \& Legoux (2009). To measure commitment we used three items drawn from Grégoire, Tripp \& Legoux (2009). Loyalty intentions were measured using four items adapted from Wagner, et al. (2009). A single-item was adapted from Wulf et al. (2001) to measure share-ofwallet. We operationalized payment source ('own money’ vs ‘others money’) by asking the question: Who usually pays (more than $80 \%$ of the time) for your airline travel when you fly with XXX airline”? The respondents were asked to select one of the three answers: (a) Yourself (own money); (b) Employer; and (c) Others, please specify For the purpose of analysis, we considered (a) as 'own money'; and combined (b) and (c) to represent 'others money'. In the final sample of 207 'demoted’ customers, ‘own money’ and ‘others money’ accounted for 64\% and 36\% respectively. Of the final sample of 203 'no change' customers, 'own money’ and 'others money’ accounted for 69\% and 31\% respectively. We determined 'purpose of travel' by asking respondents to indicate if the predominant purpose of their travel with the specified airline (more than $80 \%$ of the time) was leisure, or business.

Satisfaction, commitment and loyalty intentions were measured on a 7-point Likert scale $(1=$ strongly disagree, 7 = strongly agree), while trust was measured on a 7-point semantic differential scale. The constructs, items, reliability and validity are presented in Table 1. An examination of the correlations among the variables revealed absence of multicollinearity (see Table 2). Results of confirmatory factor analyses (CFA) suggest valid and reliable scales (see Table 1). The average variance extracted (AVE) ranged between 0.79 and 0.88 , which confirms convergent validity of the constructs (Fornell and Larcker, 1981). The composite reliability of each construct exceeded the 0.7 threshold (Hair et al., 2006). Overall our model demonstrated adequate discriminant validity and convergent validity.

\section{Insert Table 1 here}




\section{Insert Table 2 here}

\section{RESULTS}

The mean values for satisfaction, trust, and commitment for customers in the 'no change' in status category are presented in Table 3. The mean values for satisfaction, trust, and commitment (5.29, 5.60, and 5.12 respectively) for 'own money' customers are found to be significantly higher than for 'others money' customers (4.84, 4.89, and 4.81 respectively). These findings indicate that 'own money’ customers have stronger positive attitudes than 'others money’ customers, thus supporting H1a, b, c.

\section{Insert Table 3 here}

Multivariate analyses were conducted to examine the statistical significance of group differences (status change and payment source). The results (as shown in Table 4) found the differences to be statistically significant (Status Change: Wilks' $\lambda=.844$, F-ratio $=24.818, \mathrm{p}<.001$; Payment Source: Wilks' $\lambda=.975$, F-ratio $=3.381, \mathrm{p}<.05$; Status $\times$ Payment Source: Wilks' $\lambda=.930$, F-ratio $=10.183, \mathrm{p}<.001)$

\section{Insert Table 4 here}

The mean values for each of the variables; satisfaction, trust and commitment presented in Table 5 show that the mean values for all the three variables differ significantly across status change (no change and demoted) and payment source (own money and others money).

\section{Insert Table 5 here}


The interactive effects, presented in Figures 1, 2, and 3 indicate that negative effect of demotion on satisfaction, trust, and commitment are significantly stronger for 'own money’ customers than for 'others money' customers while controlling for purpose of travel. Thus, we find full support for H2a, b, c.

\section{Insert Figure 1 here}

\section{Insert Figure 2 here}

\section{Insert Figure 3 here}

Past studies have examined moderating effects in regression models through interaction variables (Bell \& Luddington, 2006; Stein \& Ramaseshan, 2015). For instance, Bell \& Luddington (2006) assessed the main effects of independent variables and moderating effects on dependent variables using interaction terms in a hierarchical moderated regression analysis. In line with this approach, we conducted hierarchical moderator regression analysis to examine the effect of satisfaction, trust, and commitment on loyalty intentions for demoted customers using interaction terms for payment source (1= “own money”; $2=$ "others money”). To test the moderating effects, we first created three multiplicative interaction terms (satisfaction $\times$ payment source; trust $\times$ payment source; commitment $\times$ payment source). To minimize problems of multicollinearity between the interaction effects and the main effects in the model we created the interaction terms by multiplying together the variables after mean centering. The results presented in Table 6 indicate that the main effect (satisfaction, trust and commitment) has a direct effect on loyalty intentions while controlling for purpose of travel (i.e., business or leisure). The regression coefficient for satisfaction $(\beta=.30 ; \mathrm{p}<.01)$, trust $(\beta=.19 ; \mathrm{p}<$ $.05)$, and commitment $(\beta=.22 ; \mathrm{p}<.05)$ are all significant and the $R^{2}$ for Model 2 is .27 . With the 
addition of the interaction terms into the model (Model 3) the main effects of satisfaction $(\beta=.16 ; p$ $<.05)$ and commitment $(\beta=.12 ; \mathrm{p}<.05)$ remain significant and the interaction terms were found to have a significant impact on loyalty intentions: satisfaction $\times$ payment source $(\beta=.15 ; \mathrm{p}<.05)$ and commitment $\times$ payment source $(\beta=.14 ; p<.05)$. This indicates that a positive change in satisfaction/commitment leads to weaker positive changes in loyalty intentions for demoted 'own money' customers than for demoted 'others money' customers, thus showing that the effect of satisfaction and commitment on loyalty intentions will be weaker for demoted 'own money' customers than for demoted 'others money' customers, hence providing support for HЗa and H3c. However, we find no support for H3b as the main effect of trust and the interaction term trust $\times$ payment source $(\beta=.02 ; \mathrm{p}>.05)$ were not found to be significant.

\section{Insert Table 6 here}

A further analysis to examine the effect of loyalty intentions on share-of-wallet (presented in Table 7) shows that the main effect of loyalty intentions on share-of-wallet $(\beta=.25 ; p<.01)$ while controlling for purpose of travel (i.e., business or leisure) is significant and the $R^{2}$ for Model 2 is .12. With the addition of the interaction term into the model (Model 3) the main effects of loyalty intentions $(\beta=.13 ; \mathrm{p}<.05)$ remain significant and the interaction term was found to have a significant impact on share-of-wallet: loyalty intentions $\times$ payment source $(\beta=.14 ; p<.05)$. This indicates that a positive change in loyalty intentions leads to weaker positive changes in share-ofwallet for demoted 'own money' customers than for demoted 'others money' customers, thus confirming support to $\mathrm{H} 4$ which states that the effect of loyalty intentions on share-of-wallet will be weaker for demoted ‘own money’ customers than for demoted ‘others money’ customers. A summary of the results of the hypotheses is presented in Table 8. 


\section{Insert Table 7 here}

\section{Insert Table 8 here}

\section{DISCUSSION}

Our study contributes to the loyalty program research and the wider relationship marketing literature in several ways. While past work has demonstrated the negative effects of demotion on purchases, to the best of our knowledge limited research to date has explored how this effect may vary across different groups of customers. Specifically, no research thus far has investigated the negative effects of demotion in hierarchical loyalty programs across distinct groups based on payment source ('own money’ versus ‘others money’). In our study, we examined the effects of demotion on customer attitudes and behavior, and explored whether payment source ('own money' versus 'others money') moderates the effect of customer attitudes on loyalty intentions, and the effect of loyalty intentions on share-of-wallet. Extending the body of research in this area, we employed the theory of psychological ownership (Pierce et al. 2001) to assess the effects of customer attitudes and behavior caused by status demotion; thus making a unique theoretical contribution to the relationship marketing literature.

Our study revealed that payment source (own money vs. others money) has significant influence on the chain of links between customer attitudes (satisfaction, trust, and commitment), loyalty intentions, and share-of-wallet. We find that customers who pay with their own money have higher satisfaction, trust, and commitment, than those who pay with others money. This is an important finding given that 'own money' customers account for over two thirds of the airline loyalty program members. We also find that the negative effects of status demotion on satisfaction, trust, and commitment, are stronger for 'own money' customers than ‘others money’ customers.

Our findings suggest the existence of dissimilarities in the effects of reciprocal exchanges between the loyalty program members and the firm. Specifically, the effects of customer demotion in 
loyalty programs are influenced by whom to attribute the labor (efforts) in achieving the status.

Status demotion seems to induce stronger negative emotions among demoted 'own money' customers than demoted 'others money’ customers. Demoted 'own money’ customers get a feeling of invasion by the airlines company into their ownership of the loyalty program (object), which in turn has stronger negative effects on the individual's attitudes and behavioral intentions towards the firm. On the other hand demoted 'others money' customers lack a feeling of ownership towards the firm as they do not attribute their loyalty program status to their own labor (efforts). This is because, the miles earned from work related travel that is paid for by the company is passed on to the employee as a valuable personal perk (Cunningham 1999) and thus not attained from employee's own labor (efforts). Basso, Clements \& Ross (2009) point out that in contexts where purchases for air travel are paid by others (e.g., employer) the normal agency relationship is between the airline and the employer who pays most (possibly all) of the cost of the purchases.

Our findings highlight that the effect of satisfaction and commitment on loyalty intentions, and the effect of loyalty intentions on share-of-wallet are weaker for demoted 'own money' customers than for demoted 'others money' customers. This is because the negative effects of demotion will be stronger for demoted 'own money' customers who have a higher tendency of feeling a sense of loss due to perceived invasion (i.e. status demotion) into something that he/she created by investment of self. On the other hand, the feeling of investment of self is non-existent among demoted 'others money' customers who have obtained the loyalty program status (object) without any investment of own labor. This highlights that investment in increasing customer satisfaction and commitment aimed at enhancing loyalty and in-turn increase the share-of-wallet will be less effective and yield significantly lower returns for demoted 'own money' customers than for demoted 'others money’ customers. Hence, it will cost more resources/efforts for firms to regain loyalty and increase share-of-wallet from demoted 'own money' customers than from demoted 'others money' customers. 
Although we found the main effect of trust on loyalty intentions to be significant, to our surprise we found that the interaction effect of payment source did not significantly influence the effect of trust on loyalty intentions. This means that the effect of trust on loyalty intentions does not significantly differ between demoted 'own money’ customers and demoted 'others money' customers. This could be presumably attributable to the fact that trust amongst individuals develops over an extended period of time (Chiu et al., 2012). Unlike satisfaction which is an affect based response to an outcome (Oliver, 1980), trust cannot be achieved or dissolved in a short span of time. The effects of satisfaction with past outcomes increase customers' confidence, which eventually contributes in building trust (Chiu et al., 2012). Firms spend substantial amount of time and resources to build relationships with customers resulting in gaining their trust, which usually does not disappear overnight based on a single event (Tuominen \& Kettunen, 2003) such as a demotion in the status of the loyalty program. Hence, payment source ('own money’ versus ‘others money’) may not be relevant to the diminishing trend of the customers' trust following a status demotion in the loyalty program.

\section{MANAGERIAL IMPLICATIONS}

This study provides empirical support for our theoretical conceptualization that payment source plays an important role on the effects of status demotion on customer attitudes and behavior in hierarchical loyalty programs. We find that 'own money' customers have stronger attitudes (customer satisfaction, trust, and commitment) than 'others money' customers. Given that 'own money' customers account for nearly two thirds of the total airline loyalty program members, it is essential for managers to pay special attention to the ‘own money’ member segment. Firms could obtain 'payment source' information of loyalty program members through loyalty program enrolment form in which customers are required to provide personal information, preferences, predominant payment source, etc. and by requesting the members to update the information periodically. 
While it is common knowledge that status demotion results in negative customer responses, we find that the negative effects of customer demotion on customer attitudes are stronger for 'own money' customers than for 'others money' customers. This finding is particularly important. While status demotion in hierarchical loyalty programs is an inevitable choice any airline has to make from time to time, caution must be exercised before effecting status demotion, particularly on 'own money’ customers. Status demotion which in general reduces customer entitlements such as free flights, upgrades, products and other services, induce feelings of invasion into ownership leading to negative emotions among ‘own money’ customers who attain the status with their own labor (efforts). Therefore the feelings of letdown by the firm are stronger for these customers. Thus there is a risk of losing them completely. On the other hand, 'others money' customers while may be disappointed with status demotion, may not necessarily switch to another provider because (i) they have no psychological ownership, and (ii) they more often than not have no choice as the entity paying for the travel makes a decision on the airline the individual will travel.

It would be useful for firms to conduct cost benefit analysis of demotion before making a decision to demote ‘own money’ members. Firms must assess the likely loss of patronage and shareof-wallet and/or potential switch by ‘own money’ members. Given the substantial negative consequences of status demotions for 'own money' members, it might be prudent to leave them in their current status tier for an extended period, even if she/he does not continue to reach the threshold miles/purchase value. Such an action would give the member a feeling of gratitude which in turn helps the firm strengthen the long term relationship and gain positive word-of-mouth from the member.

Our findings are particularly important because a firm invests significant resources into enhancing customer satisfaction, trust and commitment aimed at enhancing loyalty intentions and goodwill leading to loyalty behavior (share-of-wallet). Status demotion could possibly be endangering the goodwill and loyalty of many potentially valuable 'own money' members of loyalty programs. This is of particular concern as many service firms award elevated customer status in short 
periods and such initially elevated customers frequently lose their status after one year (Wagner et al., 2009). Hence, making reliable assessments about customers' contributions to firms' profits based on such brief periods tends to be problematic (Venkatesan, Kumar, \& Bohling, 2007). These customers may develop feelings of letdown and perceptions of unfairness by the firm as they were not given a fair chance to prove themselves as valuable customers within such a limited time frame. Also, companies must continuously remind customers proactively about the requirements to maintain an elevated status and about the decline in the customer's activity levels. In addition, the demotion decision must be preceded by acknowledgement such as personal letters from the company’s management. The additional costs of extending special treatment to 'own money' customers (who do not reach the threshold miles/purchase value) minimize the risk of driving away these valuable customers.

\section{LIMITATIONS AND FUTURE RESEARCH}

This study offers empirical support for our theoretical conceptualization of the effects of payment source on the consequences of status demotion with regards to customer attitudes, loyalty intentions and share-of-wallet in hierarchical loyalty programs. However, several limitations color the interpretation our findings. First, our study relates to airlines loyalty programs in general. Given that the criteria for loyalty status elevation/demotion, types/value of loyalty rewards, etc. vary across different airline companies, future research could examine the dynamics of status demotion vis-à-vis payment source in hierarchical loyalty programs with reference to a specific airline company. Second, as hierarchical loyalty programs model also exist in a number of other industries such as hotel chains, casinos, cruise lines and retail stores (Drèze \& Nunes, 2009) as well as in car rental companies (e.g., Hertz Gold Plus Rewards), future research could investigate status demotion in relation to payment source in these industries. Third, we classified customers into 'own money' vs 'others money' categories based on frequency of purchase. Future research could consider such classification based on the money paid towards airline travel using actual transaction data. It would 
also be useful to explore the extent to which the effects we have described here exist through a longitudinal study. Fourth, we used the theory of psychological ownership to explain the phenomenon of the effects of payment source on demoted customers' attitudes and behavior. Future studies could confirm the differences among 'own money' and 'others money' customers by measuring psychological ownership of customers. Future studies could also control for the effects of personality characteristics (e.g., age, gender, income, time interval of demotion such as within the past one month vs. 10 months before) while examining the effects of payment source on status demotions in hierarchical loyalty programs. Despite these limitations and opportunities for future research, the current study introduces insights into the role of payment source on the consequences of demotion in hierarchical loyalty programs. 


\section{REFERENCES}

Anderson, E. W., Fornell, C., \& Mazvancheryl, S. K. (2004). Customer satisfaction and shareholder value. Journal of Marketing, 68 (4), 172-185.

Anderson, C.J. \& Narus, J.A. (1990), “A model of distributor firm and manufacturer firm working relationship”, Journal of Marketing, 54 (Jan), 57-62.

Basso, L. J., Clements, M. T. \& Ross, T. W. (2009). Moral hazard and customer loyalty programs. American Economic Journal: Microeconomics, 1 (1), 101-123.

Beggan, J. K. (1992), “On the Social Nature of Nonsocial Perceptions: The Mere Ownership Effect,” Journal of Personality and Social Psychology, 62 (2), 229-237.

Bell, S. J., \& Luddington, J. A. (2006). Coping with Customer Complaints. Journal of Service Research, 8 (3), 221-233.

Belk, R. W. (1988). Possession and the extended self. The Journal of Consumer Research, 15 (2), 139-168.

Buchko, A. A. (1992). Employee ownership, attitudes, and turnover: An empirical assessment. Human Relations, 45 (7), 711-733.

Chi, N. W., \& Han, T. S. (2008). Exploring the linkages between formal ownership and psychological ownership for the organization: The mediating role of organizational justice. Journal of Occupational and Organizational Psychology, 81(4), 691-711.

Chiu, C. M., Hsu, M. H., Lai, H., \& Chang, C. M. (2012). Re-examining the influence of trust on online repeat purchase intention: The moderating role of habit and its antecedents. Decision Support Systems, 53 (4), 835-845.

Csikszentmihalyi, M., \& Rochberg-Halton, E. (1981). The meaning of things: Domestic symbols and the self. Cambridge: Cambridge University Press.

Dawes, J. (2009). The Effect of Service Price Increases on Customer Retention: The Moderating Role of Customer Tenure and Relationship Breadth. Journal of Service Research, 11 (3), 232245. 
Wulf, K.D., Odekerken-Schröder, G. \& Iacobucci, D. (2001). Investments in consumer relationships: A cross-country and cross-industry exploration. Journal of Marketing, 65 (4), $33-50$.

Druskat, V. U., \& Pescosolido, A. T. (2002). The content of effective teamwork mental models in self-managing teams: Ownership, learning and heedful interrelating. Human Relations, 55 (3), 283-314.

Drèze, X., \& Nunes, J. C. (2009). Feeling superior: The impact of loyalty program structure on consumers' perceptions of status. Journal of Consumer Research, 35 (6), 890-905.

Durkheim, E. (1957), Professional ethics and civil morals. London: Routledge and Kegan Paul.

Evanschitzky, H., Ramaseshan, B., Woisetschläger, D. M., Richelsen, V., Blut, M., \& Backhaus, C. (2012). Consequences of customer loyalty to the loyalty program and to the company. Journal of the Academy of Marketing Science, 40 (5), 625-638.

Evanschitzky, H., \& Wunderlich, M. (2006). An examination of moderator effects in the four-stage loyalty model. Journal of Service Research, 8 (4), 330-345.

Feather, N. T. (1969). Attribution of responsibility and valence of success and failure in relation to initial confidence and task performance. Journal of Personality and Social Psychology, 13 (2), 129-44.

Formanek, R. (1994). Why they collect: Collectors reveal their motivations, In Pearce, S. M. (Ed.), Interpreting objects and collections, pp. 327. Routhledge.

Fornell, C., \& Larcker, D. F. (1981). Evaluating structural equation models with unobservable variables and measurement error. Journal of Marketing Research, 18 (1), 39-50.Fullerton, G. (2003). When does commitment lead to loyalty? Journal of Service Research, 5(4), 333-344.

Garbarino, E., \& Johnson, M. S. (1999). The different roles of satisfaction, trust, and commitment in customer relationships. Journal of Marketing, 63 (2), 70-87. 
Grégoire, Y., Tripp, T. M. \& Legoux, R. (2009). When customer love turns into lasting hate: the effects of relationship strength and time on customer revenge and avoidance. Journal of Marketing, 73 (6), 18-32.

Ha, S., \& Stoel, L. (2014). Designing loyalty programs that matter to customers. The Service Industries Journal, 34 (6), 495-514.

Hair, J. F., Black, W. C., Babin, B. J., Anderson, R. E., \& Tatham, R. L. (2006). Multivariate data analysis (Vol. 6). Upper Saddle River, NJ: Pearson Prentice Hall.

Henderson, C., Beck, J. T. \& Palmatier, R. W. (2011). A review of the theoretical underpinnings of loyalty programs. Journal of Consumer Psychology, 21 (3), 256-276.

Henssen, Bart, Wim Voordeckers, Frank Lambrechts, \& Matti Koiranen. (2014) "The CEO autonomy-stewardship behavior relationship in family firms: The mediating role of psychological ownership." Journal of Family Business Strategy, 5 (3), 312-322.

Hlavinka, K. \& Sullivan, J. (2011). The Billion Member March: The 2011 COLLOQUY Loyalty Census: Growth and Trends in Loyalty Program Membership and Activity, Loyalty one Colloquy, Cincinnati, $\mathrm{OH}$.

James, W. (1890). The principles of psychology. New York: Holt.F

Jussila, I., Tarkiainen, A., Sarstedt, M. and Hair, J.F. (2015), "Individual psychological ownership: concepts, evidence, and implications for research in marketing", Journal of Marketing Theory and Practice, 23 (2), 121-139.

Kamleitner, B. \& Erki, B. (2013). Payment method and perceptions of ownership. Marketing Letters, 24 (1), 57-69.

Kim, D., Lee, S. Y., Bu, K., \& Lee, S. (2009). Do VIP programs always work well? The moderating role of loyalty. Psychology \& Marketing, 26 (7), 590-609.

Lacey, R., Suh, J., \& Morgan, R. M. (2007). Differential effects of preferential treatment levels on relational outcomes. Journal of Service Research, 9 (3), 241-256. 
Lawler, E. E. (1992). The ultimate advantage: Creating the high-involvement organization. San Francisco: Jossey-Bass.

Lee, D., Moon, J., Kim, Y. J., \& Mun, Y. Y. (2015). Antecedents and consequences of mobile phone usability: Linking simplicity and interactivity to satisfaction, trust, and brand loyalty. Information \& Management, 52 (3), 295-304.

Liu, Y. (2007). The long-term impact of loyalty programs on consumer purchase behaviour and loyalty. Journal of Marketing, 71 (4), 19-35.

Locke, J. (1690). Two treatises of government. Oxford: Oxford University Press.

Loewenstein, G. \& Issacharoff, S. (1994). Source Dependence in the Valuation of Objects. Journal of Behavioural Decision Making, 7 (3), 157-168.

Long, R. J. (1978). The effects of employee ownership on organizational identification, employee job attitudes, and organizational performance: A tentative framework and empirical findings. Human Relations, 31 (1), 29-48.

Mayhew, M.G., Ashkanasy, N. M., Bramble, T. \& Gardner, J. (2007). A study of the antecedents and consequences of psychological ownership in organizational settings. The Journal of social psychology, 147 (5), 477-500.

Melnyk, V., \& Bijmolt, T. (2015). The effects of introducing and terminating loyalty programs. European Journal of Marketing, 49 (3/4), 398-419.

McIntosh, R. W., \& Goeldner, C. R. (1990). Tourism: Principles, Practices, Philosophies. New York: John Wiley.

Morgan, M.R. \& Hunt, S.D. (1994), “The commitment-trust theory of relationship marketing”, Journal of Marketin,. 58 (3), 20-38.

Morrison, A. M. (1996). Hospitality and Travel Marketing. Albany, NY: Delmar.

Nuttin, J. M., Jr. (1987), “Affective Consequences of Mere Ownership: The Name Letter Effect in Twelve European Languages,” European Journal of Social Psychology, 17 (4), 381-402. 
Oliver, R. (1997). Satisfaction: A behavioural perspective on the consumer. New York: Irwin McGraw-Hill.

Oliver, R. L. (1980). A cognitive model of the antecedents and consequences of satisfaction decisions. Journal of Marketing Research, 17 (4), 460-469.

Paulssen, M., Roulet, R., \& Wilke, S. (2014). Risk as moderator of the trust-loyalty relationship. European Journal of Marketing, 48 (5/6), 964-981.

Pierce, J. L., Kostova, T. \& Dirks, K.T. (2001). Toward a theory of psychological ownership in organizations. Academy of Management Review, 26 (2), 298-310.

Pierce, J. L., Kostova, T. \& Dirks, K. T. (2003). The state of psychological ownership: Integrating and extending a century of research. Review of General Psychology, 7 (1), 84.

Podsakoff, P. M., Mackenzie, S. B., Lee, J. Y., \& Podsakoff, N. P. (2003). Common method biases in behavioral research: A critical review of the literature and recommended remedies. Journal of Applied Psychology, 88 (5), 879-903.

Reinke, S. J. (2004). Service before self: Towards a theory of servant-leadership. Global Virtue Ethics Review, 5(3), 30.

Scheer, L.K. \& Stern, L.W. (1992), “The effect of influence type and performance outcomes on attitude towards the influencer”, Journal of Marketing Research, 29 (1), 128-42.

Smith, D. (2002). The Humiliating Organization: The Functions and Dysfunctions of Degradation. In The Civilized Organization: Norbert Elias and the Future of Organization Studies, Iterson, A. V., Mastenbroek, W., Newton, T., \& Smith, D. (Eds.) Philadelphia: John Benjamins Publishing, 41-57.

Stein, A., \& Ramaseshan, B. (2015). Customer Referral Behaviour: Do Switchers and Stayers Differ? Journal of Service Research, 18 (2), 229-239.

Trice, H. M., \& Beyer, J. M. (1984). Studying Organizational Cultures through Rites and Ceremonials. Academy of Management Review, 9 (4), 653-69. 
Tuominen, P., \& Kettunen, U. (2003). To fade or not to fade? That is the question in customer relationships, too. Managing Service Quality, 13 (2), 112-123.

van Berlo, G., Bloemer, J. \& Blazevic, V. (2014). Customer demotion in hierarchical loyalty programmes. The Service Industries Journal, 34 (11), 922-937.

Van Dyne, L., \& Pierce, J.L. (2004), "Psychological ownership and feelings of possession: Three field studies predicting employee attitudes and organizational citizenship behavior." Journal of organizational behavior 25 (4), 439-459.

Venkatesan, R., Kumar, V., \& Bohling, T. (2007). Optimal customer relationship management using Bayesian decision theory: An application for customer selection, Journal of Marketing Research, 44 (4), 579-594.

Verhoef, P. C. (2003). Understanding the effect of customer relationship management efforts on customer retention and customer share development, Journal of marketing, 67 (4), 30-45.

Verhoef, C.P., Franses, P.H. \& Hoekstra, J.C. (2002), “The effect of relational constructs on customer referrals and number of services purchased from a multiservice provider: does age of relationship matter?”, Journal of the Academy of Marketing Science, 30 (3), 202-16.

Vogel, V., Evanschitzky, H., \& Ramaseshan, B. (2008). Customer equity drivers and future sales. Journal of marketing, 72 (6), 98-108.

Wagner, T., Hennig-Thurau, T. \& Rudolph, T. (2009). Does customer demotion jeopardize loyalty? Journal of Marketing, 73 (3), 69-85.

Weiner, B. (1985). An attributional theory of achievement motivation and emotion. Psychological Review, 92 (4), 548-73.

Wirtz, J., Mattila, A. S., \& Lwin, M. O. (2007). How effective are loyalty reward programs in driving share of wallet? Journal of Service Research, 9 (4), 327-334.

Yi, Y., \& Jeon, H. (2003). Effects of loyalty programs on value perception, program loyalty, and brand loyalty. Journal of the Academy of Marketing Science, 31 (3), 229-240. 
Table 1: Constructs, measures and reliability

\begin{tabular}{|c|c|c|c|}
\hline Construct & Items & $\begin{array}{c}a^{*} \\
{\left[\mathrm{CR}^{* *}\right]}\end{array}$ & CFA*** \\
\hline Satisfaction & $\begin{array}{l}\text { 1. I am satisfied with my decision to join XXX airline loyalty } \\
\text { program. }\end{array}$ & $\begin{array}{c}.926 \\
{[0.95]}\end{array}$ & .899 \\
\hline Oliver (1980) & $\begin{array}{l}\text { 2. My choice to join XXX airline loyalty program was a wise one. } \\
\text { 3. I am unhappy that I joined XXX airline loyalty program. [R] } \\
\text { 4. I think I did the right thing in using XXX airline loyalty } \\
\text { program. }\end{array}$ & & $\begin{array}{l}.889 \\
.918 \\
.784\end{array}$ \\
\hline Trust & $\begin{array}{l}\text { I feel that XXX airline loyalty program is: } \\
\text { 1. Very undependable - very dependable }\end{array}$ & $\begin{array}{c}.943 \\
{[0.96]}\end{array}$ & .908 \\
\hline $\begin{array}{l}\text { Grégoire, Tripp and } \\
\text { Legoux (2009) }\end{array}$ & $\begin{array}{l}\text { 2. Very incompetent - very competent } \\
\text { 3. Of low integrity - of high integrity } \\
\text { 4. Very unresponsive to consumers - very responsive consumers }\end{array}$ & & $\begin{array}{l}.930 \\
.899 \\
.857\end{array}$ \\
\hline & $\begin{array}{l}\text { 1. I am very committed to my relationship with } \mathrm{XXX} \text { airline } \\
\text { loyalty program. }\end{array}$ & $\begin{array}{c}.860 \\
{[0.92]}\end{array}$ & .830 \\
\hline $\begin{array}{l}\text { Grégoire, Tripp and } \\
\text { Legoux (2009) }\end{array}$ & $\begin{array}{l}\text { 2. The relationship with XXX airline loyalty program is } \\
\text { something I intended to maintain for a long time. } \\
\text { 3. I put efforts into maintaining my relationship with XXX airline } \\
\text { loyalty program. }\end{array}$ & & $\begin{array}{l}.882 \\
.754\end{array}$ \\
\hline Loyalty Intentions & $\begin{array}{l}\text { 1. I will continue flying with XXX airline. } \\
\text { 2. The next time I need air travel, I will choose XXX airline. }\end{array}$ & $\begin{array}{c}.920 \\
{[0.96]}\end{array}$ & $\begin{array}{l}.866 \\
.904\end{array}$ \\
\hline $\begin{array}{l}\text { Wagner, Hennig- } \\
\text { Thurau and Rudolph } \\
\text { (2009) }\end{array}$ & $\begin{array}{l}\text { 3. I will consider XXX airline as my first choice for air travel. } \\
\text { 4. I will use the services of XXX airline in the future. }\end{array}$ & & $\begin{array}{l}.889 \\
.825\end{array}$ \\
\hline
\end{tabular}

Share-of-Wallet Based on your travel will all airlines in the past 12 months, what

percentage of air travel was made from XXX airline?

$\begin{array}{ll}\text { Wulf et al., (2001) } & 1.0 \%-20 \% \\ & \text { 2. } 21 \%-40 \% \\ & 3.41 \%-60 \% \\ & 4.61 \%-80 \% \\ & 5.81 \%-100 \%\end{array}$

Payment Source Who usually pays (more than $80 \%$ of the time) for your airline travel when you fly with XXX airline?

1. I pay with my own money

2. Someone else pays (e.g., employer, others-please specify__ ( )
Loyalty Program In the last 12 months was there any change in your airline loyalty Status Change program status?
1. Promoted
2. No Change
3. Demoted




Table 2: Correlations

\begin{tabular}{lcccccccc}
\hline Variable & Mean & SD & AVE & $\mathbf{1}$ & $\mathbf{2}$ & $\mathbf{3}$ & $\mathbf{4}$ & $\mathbf{5}$ \\
\hline 1. Satisfaction & 4.62 & 1.35 & 0.85 & 1 & & & & \\
2. Trust & 4.88 & 1.36 & 0.88 & $.67^{* *}$ & 1 & & & \\
3. Commitment & 4.52 & 1.10 & 0.79 & $.57^{* *}$ & $.58^{* *}$ & 1 & & \\
4. Loyalty & 4.54 & 1.50 & 0.86 & $.68^{* *}$ & $.64^{* *}$ & $.57^{* *}$ & 1 & \\
intentions & & & & & & & & \\
5. Share-of-wallet & 2.94 & 1.34 & - & $.44^{* *}$ & $.45^{* *}$ & $.41^{* *}$ & $.40^{* *}$ & 1 \\
\hline \multicolumn{2}{c}{ Note: ${ }^{* *} \mathrm{p}<.01$} & & & & & & &
\end{tabular}


Table 3: Mean values of customer attitude variables: ‘own money’ versus 'others money' 'no change' in status category

\begin{tabular}{|c|c|c|c|c|c|}
\hline \multirow[t]{2}{*}{ Variable } & \multicolumn{2}{|c|}{ Own Money } & \multicolumn{2}{|c|}{ Others Money } & \multirow[t]{2}{*}{ t-Value } \\
\hline & Mean & SD & Mean & SD & \\
\hline Satisfaction & 5.29 & .99 & 4.84 & 1.15 & $2.50 *$ \\
\hline Trust & 5.60 & .84 & 4.89 & 1.18 & $4.36 * *$ \\
\hline Commitment & 5.12 & .78 & 4.81 & .85 & $2.25 *$ \\
\hline
\end{tabular}

Note: ${ }^{*} \mathrm{p}<0.05 ;{ }^{* *} \mathrm{p}<0.01$ 
Table 4: Multivariate test

\begin{tabular}{lcc}
\hline Effect & Wilks' $\boldsymbol{\lambda}$ & F-ratio \\
\hline Status Change & .844 & $24.818^{* *}$ \\
Payment Source & .975 & $3.381^{*}$ \\
Status $\times$ Payment Source & .930 & $10.183^{* *}$ \\
\hline
\end{tabular}

Note: ${ }^{*} \mathrm{p}<.05 ;{ }^{* *} \mathrm{p}<.01$ 
Table 5: Means for interaction effect

\begin{tabular}{cccccccccc}
\hline & \multicolumn{3}{c}{ Satisfaction } & \multicolumn{3}{c}{ Trust } & \multicolumn{3}{c}{ Commitment } \\
& $\begin{array}{c}\text { Own } \\
\text { Money }\end{array}$ & $\begin{array}{c}\text { Others } \\
\text { Money }\end{array}$ & t-Value & $\begin{array}{c}\text { Own } \\
\text { Money }\end{array}$ & $\begin{array}{c}\text { Others } \\
\text { Money }\end{array}$ & t-Value & $\begin{array}{c}\text { Own } \\
\text { Money }\end{array}$ & $\begin{array}{c}\text { Others } \\
\text { Money }\end{array}$ & t-Value \\
\hline $\begin{array}{c}\text { Status Change } \\
\text { - No Change }\end{array}$ & 5.29 & 4.84 & $2.49^{*}$ & 5.60 & 5.02 & $4.35^{* *}$ & 5.12 & 4.81 & $2.25^{*}$ \\
$\quad$ - Demoted & 3.80 & 4.54 & $-3.72^{* *}$ & 4.19 & 4.54 & $-1.62^{*}$ & 3.73 & 4.50 & $-4.99^{* *}$ \\
\hline
\end{tabular}

Note: ${ }^{*} \mathrm{p}<0.05 ;{ }^{* *} \mathrm{p}<0.01$ 
Table 6: Hierarchical moderated regression analysis for loyalty intentions

\begin{tabular}{|c|c|c|c|c|c|c|}
\hline & \multicolumn{2}{|c|}{ Model 1} & \multicolumn{2}{|c|}{ Model 2} & \multicolumn{2}{|c|}{ Model 3} \\
\hline & $\beta$ & $t$ Value & $\beta$ & $t$ Value & $\beta$ & $t$ Value \\
\hline \multicolumn{7}{|l|}{ Control } \\
\hline Purpose of travel & .54 & $2.44^{*}$ & .24 & 1.21 & .34 & 1.79 \\
\hline \multicolumn{7}{|l|}{ Main effects } \\
\hline Satisfaction & & & .30 & $3.67 * *$ & .16 & $1.79 *$ \\
\hline Trust & & & .19 & $2.42 *$ & .17 & 1.54 \\
\hline Commitment & & & .22 & $2.24^{*}$ & .12 & $1.27 *$ \\
\hline \multicolumn{7}{|l|}{ Moderators } \\
\hline Satisfaction $\times$ Payment source & & & & & .15 & $2.48 *$ \\
\hline Trust $\times$ Payment source & & & & & .02 & .22 \\
\hline Commitment $\times$ Payment source & & & & & .14 & $2.23 *$ \\
\hline$R^{2}$ & .03 & & .27 & & .35 & \\
\hline$F$ statistic & $5.94 *$ & & $15.50 * *$ & & $12.73 * *$ & \\
\hline Change in $R^{2}$ & & & .24 & & .08 & \\
\hline Change in $F$ statistic & & & $18.10^{* *}$ & & $6.87 * *$ & \\
\hline
\end{tabular}

Note: Dependent variable: loyalty intentions; Source of payment: $1=$ own money, $2=$ others money

$* \mathrm{p}<0.05 ; * * \mathrm{p}<0.01$ 
Table 7: Hierarchical moderated regression analysis for share-of-wallet

\begin{tabular}{|c|c|c|c|c|c|c|}
\hline & \multicolumn{2}{|c|}{ Model 1} & \multicolumn{2}{|c|}{ Model 2} & \multicolumn{2}{|c|}{ Model 3} \\
\hline & $\beta$ & $t$ Value & $\beta$ & $t$ Value & $\beta$ & $t$ Value \\
\hline Control & & & & & & \\
\hline Purpose of travel & .62 & $3.06^{* *}$ & .49 & $2.45^{*}$ & .49 & $2.51^{*}$ \\
\hline Main effects & & & & & & \\
\hline Loyalty intentions & & & .25 & $3.69 * *$ & .13 & $1.92 *$ \\
\hline $\begin{array}{l}\text { Moderators } \\
\text { Loyalty intentions } \times \text { Payment } \\
\text { source }\end{array}$ & & & & & .14 & $2.36 *$ \\
\hline $\begin{array}{l}R^{2} \\
F \text { statistic } \\
\text { Change in } R^{2} \\
\text { Change in } F \text { statistic }\end{array}$ & $\begin{array}{c}.05 \\
9.39 * *\end{array}$ & & $\begin{array}{c}.12 \\
11.83^{* *} \\
.07 \\
13.59 * * \\
\end{array}$ & & $\begin{array}{c}.15 \\
9.95^{* *} \\
.03 \\
5.56^{*}\end{array}$ & \\
\hline
\end{tabular}

Note: Dependent variable: share-of-wallet; Source of payment: 1 = own money, 2 = others money

* $\mathrm{p}<0.05 ; * * \mathrm{p}<0.01$ 
Table 8: Summary of Hypotheses

\begin{tabular}{|c|c|c|c|c|}
\hline & Hypothesis & Own & Others & Hypothesis \\
\hline H1a & $\begin{array}{l}\text { 'Own money’ customers will have higher } \\
\text { satisfaction towards a company than 'others money’ } \\
\text { customers. }\end{array}$ & Higher & Lower & Supported \\
\hline $\mathrm{H} 1 \mathrm{~b}$ & $\begin{array}{l}\text { 'Own money' customers will have higher trust } \\
\text { towards a company than 'others money’ customers. }\end{array}$ & Higher & Lower & Supported \\
\hline $\mathrm{H} 1 \mathrm{c}$ & $\begin{array}{l}\text { 'Own money' customers will have higher } \\
\text { commitment towards a company than 'others } \\
\text { money’ customers. }\end{array}$ & Higher & Lower & Supported \\
\hline $\mathrm{H} 2 \mathrm{a}$ & $\begin{array}{l}\text { The negative effect of demotion on satisfaction } \\
\text { towards a company is stronger for 'own money' } \\
\text { customers than 'others money' customers. }\end{array}$ & Stronger & Weaker & Supported \\
\hline $\mathrm{H} 2 \mathrm{~b}$ & $\begin{array}{l}\text { The negative effect of demotion on trust towards a } \\
\text { company is stronger for 'own money' customers } \\
\text { than 'others money' customers. }\end{array}$ & Stronger & Weaker & Supported \\
\hline $\mathrm{H} 2 \mathrm{c}$ & $\begin{array}{l}\text { The negative effect of demotion on commitment } \\
\text { towards a company is stronger for 'own money' } \\
\text { customers than 'others money' customers. }\end{array}$ & Stronger & Weaker & Supported \\
\hline НЗа & $\begin{array}{l}\text { The effect of satisfaction on loyalty intentions will } \\
\text { be weaker for demoted 'own money' customers than } \\
\text { for demoted 'others money' customers. }\end{array}$ & Weaker & Stronger & Supported \\
\hline H3b & $\begin{array}{l}\text { The effect of trust on loyalty intentions will be } \\
\text { weaker for demoted 'own money' customers than for } \\
\text { demoted 'others money' customers. }\end{array}$ & Weaker & Stronger & $\begin{array}{c}\text { Not } \\
\text { Supported }\end{array}$ \\
\hline НЗс & $\begin{array}{l}\text { The effect of commitment on loyalty intentions will } \\
\text { be weaker for demoted 'own money' customers than } \\
\text { for demoted 'others money' customers. }\end{array}$ & Weaker & Stronger & Supported \\
\hline $\mathrm{H} 4$ & $\begin{array}{l}\text { The effect of loyalty intentions on share-of-wallet } \\
\text { will be weaker for demoted 'own money' customers } \\
\text { than for demoted 'others money' customers. }\end{array}$ & Weaker & Stronger & Supported \\
\hline
\end{tabular}


Figure 1: Satisfaction and demotion: Interaction effect of own money/others money

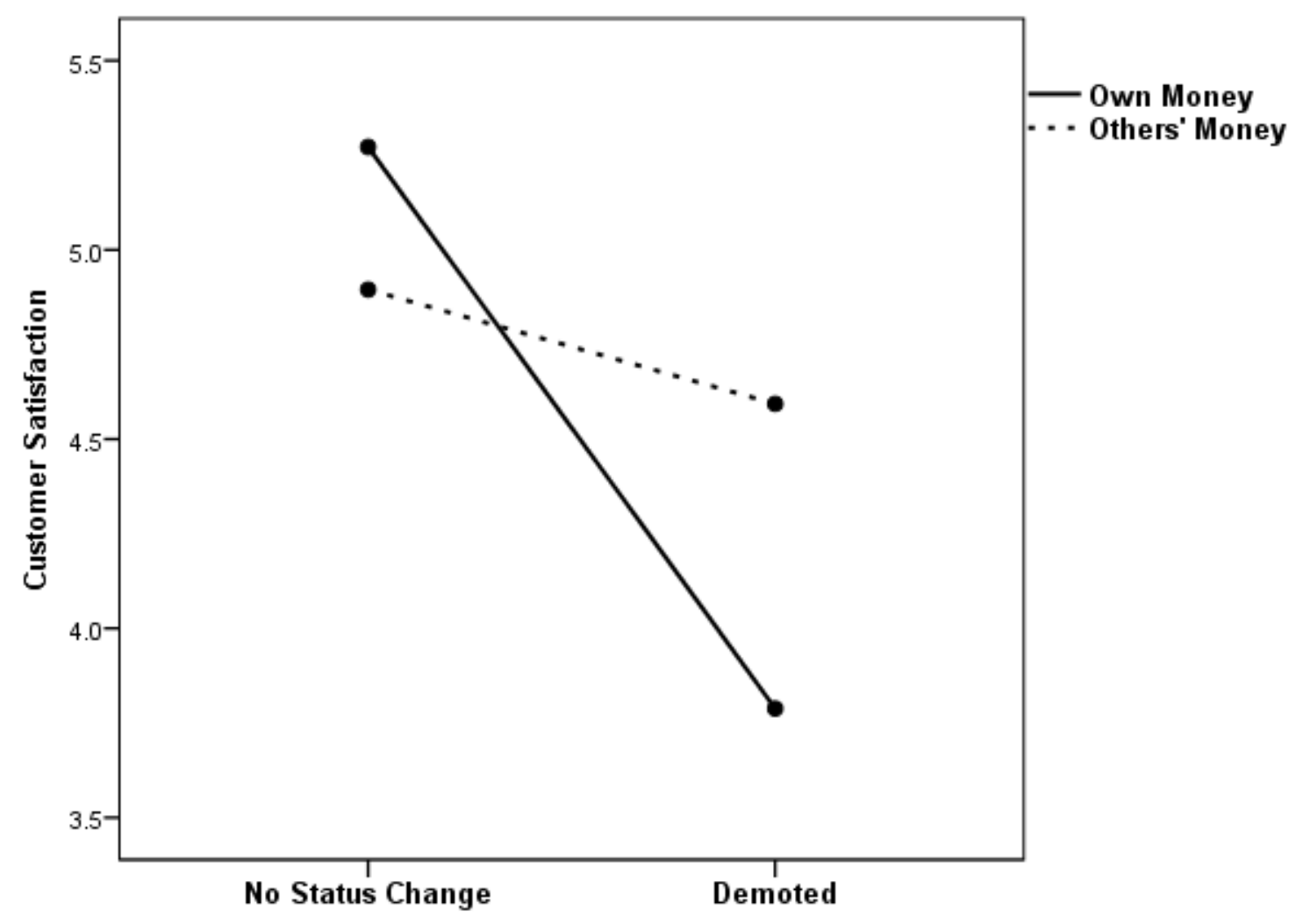

Covariates appearing in the model are evaluated at the following values: Purpose of travel $=1.29$ 
Figure 2: Trust and demotion: Interaction effect of own money/others money

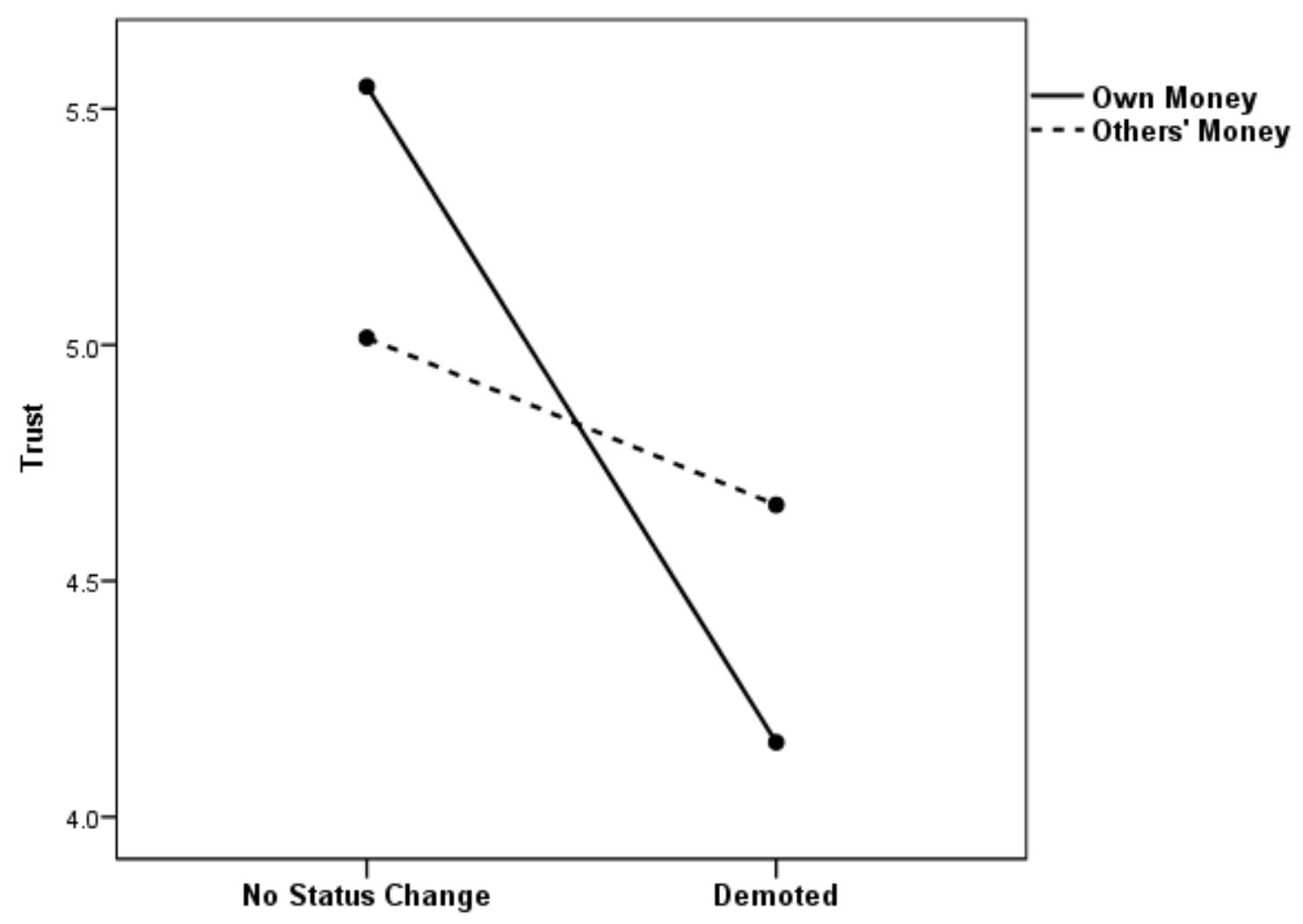

Covariates appearing in the model are evaluated at the following values: Purpose of travel $=1.29$ 
Figure 3: Commitment and demotion: Interaction effect of own money/others money

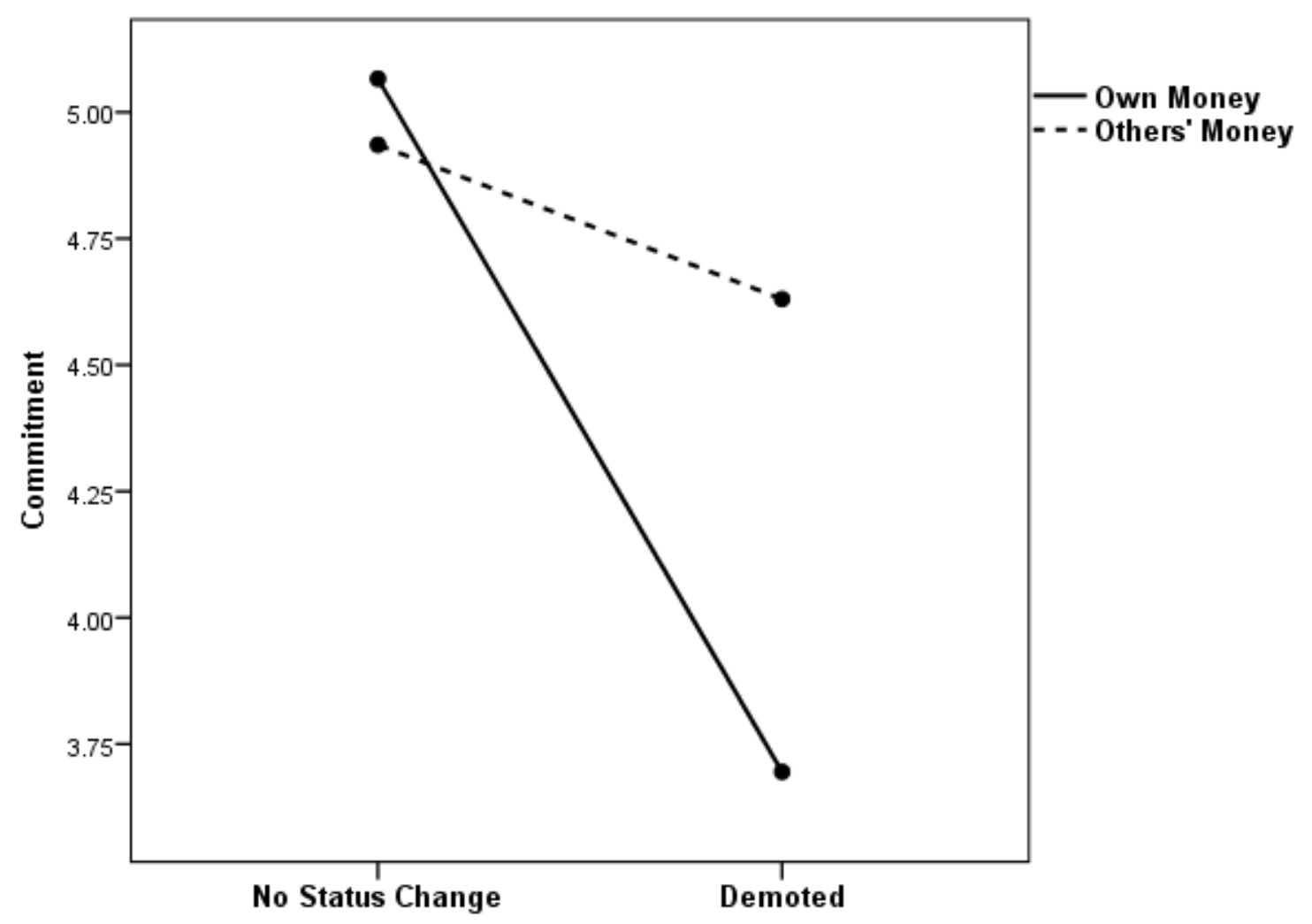

Covariates appearing in the model are evaluated at the following values: Purpose of travel $=1.29$ 